\title{
PENGARUH STANDART SARANA DAN PRASARANA TERHADAP EFEKTIFITAS PEMBELAJARAN DI TK AL-FIRDAUS
}

\author{
Nurhafit Kurniawan \\ IKIP PGRI Jember \\ ( nurhafit@yahoo.com )
}

\begin{abstract}
This research entitled "Influence standard of facilities and infrastructure to the effectiveness of learning in Kindergarten Al-Firdaus "the problem discussed in this research is how much influence the means of prasana to KBM process that exist in kindergarten $\mathrm{Al}$ pardaus, purpose of this research to know influence of facility and infrastructure to effectiveness KBM TK Al Firdaus. Methods in the study using descriptive correlational analysis, Vareabel Implementation of Standard Means and Infrastructure $(\mathrm{X})$ is one of the resources that must be managed and improved continuously along with the development of science and technology, Vareabel Learning Effectiveness (Y) a deliberate, purposive, and controlled effort in order for others to learn or relative permanent change in others / or institution / kindergarten Alfirdaus, data processing in this study using statistical methods assisted excel program 2007 and SPSS 17.0. Based on the results of research data obtained through a questionnaire-shaped instrument, then given a score on each alternative answers given by the respondent in accordance with the weight that has been set. Each statement in the three variables has 5 answer criteria with scoring starting from 1,2, 3 , 4, and 5 with terms for statements calculated with the results of descriptive calculations. Classroom conditions in kindergarten Al-Firdaus 13.33\% - 26.67\% in lightly damaged condition, while the rest is very suitable to use. Learning media such as props, learning etc. are also complete, which is very concerned is the school computers that achieve 40-60\% damage even more inadequate amounts are also specifications that lag far behind. Based on the research results can be concluded that one effort that can be done to improve the Effectiveness of Learning in kindergarten $\mathrm{Al}$ Firdaus is by improving facilities and infrastructure.
\end{abstract}

Keywords: Facilities and Infrastructure, Effectiveness of Learning.

\section{PENDAHULUAN}

Pada hakikatnya pendidikan bersumber dari adanya kebutuhan manusia untuk beradaptasi dengan lingkungan dimana mereka hidup dan berproses, Pendidikan dapat tumbuh dan berkembang secara maximal serta optimal dengan adanya perkembangan penyelenggaraan pendidikan yang sesuai dengan tuntutan zaman, Dengan demikian pendidikan yang baik perlu kiranya membahas tentang komponen yang ada dalam pendidikan, Komponen pendidikan terdiri dari tujuan, pendidik, peserta didik, kurikulum, fasilitas serta lingkungan. Komponen pendidikan harus saling bersinergi dan mendukung satu sama lain Keberhasilan pendidikan di suatu sekolah hal ini dipengaruhi oleh berbagai faktor diantaranya tersedia sarana prasarana pendidikan yang 
Jurnal Warna : Jurnal Pendidikan Dan Pembelajaran Anak Usia dini. September 2017. Vol 02. No. 02

mumpuni secara kuantitas, melalui sarpras yang lengkap akan terlaksananya proses Pembelajaran Aktif Kreatif Efektif dan Menyenangkan (PAKEM). kegiatan pembelajaran dan pengajaran mampu berlangsung secara maximal apabila didukung dengan sarana yang baik, sarana tersebut adalah berupa alat bantu mengajar, laboratorium, aula, lapangan olah raga, serta berbagai sarana pendukung lainnya. Dalam manajemen pendidikan kegiatan pembelajaran merupakan hal vital yang harus tertata serta terorganisir dengan baik adapun beberapa tahap untuk mengorganisir kegiatan tersebut diantaranya sebagai berikut :

\section{Perencanaan Sarana dan Prasarana}

Perencanaan adalah syarat wajib yang harus dipenuhi di setiap kegiatan pengelolaan sarana dan prasarana. Ketika Tidak adanya perencanaan, berbagai kegiatan akan mengalami banyak masalah dan mungkin kegagalan.

Membuat rencana kegiatan merupakan tindakan awal suatu pekerjaan karena suatu keberhasian tidak semata mata ditentukan sendiri tingkat keberhasilannya, namun banyak faktor lain yang harus dipersiapkan untuk mendukung keberhasilannya.

Seperti yang telah disampaikan oleh beberapa pakar diantaranya Surya, (2003:118) beliau mengemukan bahwa
Dalam peningkatan kuwalitas pelayanan pendidikan yang diantaranya langkahlangkah dalam manajemen sarpras maka perencanaan merupakan langkah pertama. Perencanaan bisa diartikan mengenai pemilihan dari beberapa pilihan tentang penetapan prosedur pencapaian serta perkiraan sumber yang dapat disediakan untuk mencapai target yang diharapkan, Keberhasilan pendidikan di suatu sekolah dipengaruhi oleh berbagai faktor diantaranya tersedia sarana prasarana pendidikan yang mumpuni secara kualitas maupun kuantitas, dengan sarana dan prasarana yang lengkap akan terlaksananya proses Pembelajaran Aktif Kreatif Efektif dan Menyenangkan (PAKEM). Proses pembelajaran dan pengjaran akan berlangsung secara efektif apabila ditunjang dengan sarana yang baik, sarana tersebut adalah berupa alat bantu mengajar, laboratorium, aula, lapang olah raga, dsb Surya, (2003:118). dari pemahaman Perencanaan tersebut perencaan masih bisa dibagi menjadi beberapa aspek diantaranya:

\section{A. Perencanaan kebutuhan}

Perencanaan kebutuhan merupakan rincian dari fungsi perencanaan yang mempertimbangkan faktor kebutuhan yang harus dipenuhi. Dalam menentukan kebutuhan dibutuhkan beberapa data awal diantaranya adalah distribusi dan 
Jurnal Warna : Jurnal Pendidikan Dan Pembelajaran Anak Usia dini. September 2017. Vol 02. No. 02

komposisi, jenis, jumlah, kualitas, sehingga berhasil guna tetap berdaya guna dan kebutuhan juga dikaji lebih lanjut untuk disesuaikan dengan besarnya pembiayaan dari dana yang ada.

\section{B. Perencanaan pengelolaan}

Perencanaan pengelolaan meliputi pengelolaan fasilitas KBM dari seperangkat kegiatan yang berurutan dimulai dari (1) pengumpulan dan pengolahan data, (2) analisis kebutuhan untuk fasilitas, (3) perumusan kebutuhan fasilitas, (4) penentuan prioritas kebutuhan fasilitas, dan (5) perincian rencana kebutuhan fasilitas

$\begin{array}{lcr}\text { Adapun } & \text { langkah } & \text { langkah } \\ \text { perencanaan } & \text { pengadaan } & \text { sarana } \\ \text { pendidikan } & \text { Bouni Soekarno } & (1987)\end{array}$

sebagai berikut : (1) menampung semua usulan pengadaan perlengkapan sekolah yang diajukan unit kerja sekolah, (2) menyusun rencana kebutuhan perlengkapan sekolah untuk preode tertentu, (3) Memadukan rencana kebutuhan yang telah disusun dengan perlengkapan yang telah tersedia sebelumnya (4) memadukan rencana kebutuhan dengan dana atau anggaran sekolah yang tersedia, (5) mengadakan seleksi dengan skala prioritas penetapan rencana pengadaan akhir.

\section{Pengadaan Sarana Prasarana}

Pemenuhan sarpras ialah kegiatan untuk mengadakan semua kebutuhan keperluan baik barang, benda atau jenis barang bagi keperluan pelaksanaan tugas untuk mencapai target pendidikan. Dalam pemenuhan barang memang tidak terlepas dari perencanaan pengadaan yang telah disusun sebelumnya baik mengenai jumlah maupun jenisnya. Pengadaan perlengkapan pendidikan pada dasarnya merupakan upaya merealisasikan rencana pengadaan perlengkapan yang disusun sebelumnya Bafadal (2004: 30).

Berdasar jenisnya bahwa pengadaan sarpras meliputi: (1) pengadaan tempat, (2) pengadaan bangunan; membangun baru, membeli bangunan, menyewa bangunan, menerima hibah bangunan, Pengadaan alat ; membeli, membuat sendiri, menerima hibah (4) Pengadaan ATK pendidikan; Membeli, menerima hibah ataupun daur ulang.

\section{Inventarisasi Sarana Prasarana}

Inventarisasi adalah pencatatan dan penyusunan daftar barang dalam hal ini lembaga sekolah secara tersistem berdasarkan ketentuan ketentuan atau pedoman yang berlaku. Sesuai dengan SK menteri keuangan RI Nomor Kep. 225/MK/V/4/1971 barang milik negara adalah berupa semua barang yang berasal 
Jurnal Warna : Jurnal Pendidikan Dan Pembelajaran Anak Usia dini. September 2017. Vol 02. No. 02

atau dibeli dari dana yang bersumber, baik secara keseluruhan atau sebagian dari Anggaran Pendapatan Belanja Negara (APBN) atau dana lainnya yang barang barangnya dibawah penguasaan pemerintah, baik pusat, propinsi maupun daearah.

Adapun hubungan sarana dan prasarana dengan proses pendidikan yang ada di TK Al- Firdaus dapat dikatakan bahwa sarana dan prasarana pendidikan dapat didefinisikan sebagai proses kerja sama guna memaksimalkan semua sarana dan prasarana pendidikan secara efektif. Definisi ini menunjukkan bahwa sarpras yang ada di TK Al- Firdaus perlu dimaksimalkan dan dikelola dengan baik dengan harapan untuk kepentingan proses pembelajaran di TK Al- Firdaus.

\section{METODE PENELITIAN}

Penelitian ini menggunakan pendekatan kuantitatif. Analisa terhadap fokus permasalahan dilakukan dengan menggunakan metode analisis deskriptif korelasional. Penelitian korelasi digunakan karena yang diteliti adalah Pengaruh Implementasi Standar Sarana dan Prasarana Terhadap Efektifitas Pembelajaran di TK AL Firdaus. Penelitian korelasional merupakan penelitian yang dimaksudkan untuk mengetahui ada tidaknya hubungan antara dua atau beberapa variabel." (Arikunto, S., 1993:326). Sumber data yang menjadi analisis penelitian ini adalah seluruh komponen yang menunjang judul penelitian ini yaitu kepala sekolah, guru, dan komite sekolah TK Al Firdaus.

\section{Populasi Penelitian}

Surakhmad berpendapat (1998: 93) "populasi adalah sekelompok subjek, baik manusia, gejala, nilai tes, bendabenda ataupun peristiwa, jenis data yang digunakan dalam penelitian”. Diperkuat oleh Sugiyono (2007:90) yang mengatakan:

" bahwa populasi adalah wilayah generalisasi yang terdiri atas objek atau subjek yang mempunyai kualitas dan karakteristik tertentu yang ditetapkan oleh peneliti untuk dipelajari dan kemudian ditarik kesimpulannya.

\section{Sampel}

Setelah populasi ditentukan, langkah selanjutnya adalah menentukan sampel agar bisa terlaksana pengumpulan data. Sampel adalah bagian dari populasi yang dijadikan objek penelitian, yang dianggap dapat mewakili seluruh populasi. Sugiyono mengemukakan bahwa sampel ialah bagian dari jumlah serta karakteristik yang dimiliki terhadap populasi. Sampel adalah sebagian atau wakil populasi yang diteliti. Dinamakan penelitian sampel apabila kita bermaksud untuk menggeneralisasikan hasil penelitiaanya. Berkaitan dengan teknik pengambilan 
Jurnal Warna : Jurnal Pendidikan Dan Pembelajaran Anak Usia dini. September 2017. Vol 02. No. 02

sampel, Arikunto (2005:120) mengemukakan bahwa: Untuk sekedar perkiraan apabila subjek kurang dari 100, maka lebih baik diambil semua, sehingga penelitiannya merupakan penelitian populasi. Selanjutnya jika subjek besar, dapat diambil antara 10\%-15\% atau 20\%$25 \%$ atau lebih. Berdasarkan data dari jumlah populasi penelitian di atas yang berjumlah 5 orang dan subjek kurang dari 100, maka lebih baik diambil semua, sehingga penelitiannya merupakan penelitian populasi.

\section{Vareabel Penelitian}

Berikut ini adalah definisi oprasional variabel penelitian :

\section{Vareabel Implementasi Standar}

Sarana dan Prasarana $(X)$

adalah salah satu sumber daya yang harus dikelola dan ditingkatkan terus menerus seiring dengan perkembangan ilmu pengetahuan dan teknologi. Kegiatan suatu organisasi memerlukan manajemen. Pada prinsipnya manajemen adalah sama pentingnya dengan pengurusan dan pengelolaan. Manajemen iyalah serangkaian kegitan yang ditata, dirancang, dikelola untuk mencapai tujuan organisasi. Manajemen sarana prasarana pendidikan merupakan seluruh proses kegiatan yang direncanakan secara sengaja dan bersungguh sungguh serta pembinaan secara kontinyu terhadap benda benda pendidikan, agar senantiasa siap kerja dalam proses belajar mengajar sehingga proses belajar mengajar semakin efektif dan efesien guna membantu tercapainya tujuan pendidikan yang telah ditetapkan.

2. Vareabel Efektifitas Pembelajaran ( $Y$ )

Suatu usaha yang bertujuan, dan terkendali agar orang lain belajar atau terjadi perubahan yang relatif menetap pada diri orang lain. kegiatan ini bisa disalurkan oleh seseorang atau suatu tim yang memiliki kemampuan dan kompetensi dalam merancang dan atau menyumbangkan sumber belajar yang butuhkan. Pengertian ini dibedakan dengan pengajaran yang mengandung arti penyajian bahan ajar yang dilakukan oleh seorang pengajar. Pembelajaran tidak harus diberikan oleh pengajar, karena kegiatan itu dapat dilakukan oleh perancang dan pengembang sumber belajar, misalnya seorang teknolog pembelajaran, suatu tim terdiri dari ahli media ataupun ahli materi pelajaran tertentu.

Berkaitan dengan bagaimana kontribusi dan hubungan keterpengaruhan diantara variabelvariabel tadi, dapat dilihat pada gambar berikut ini :

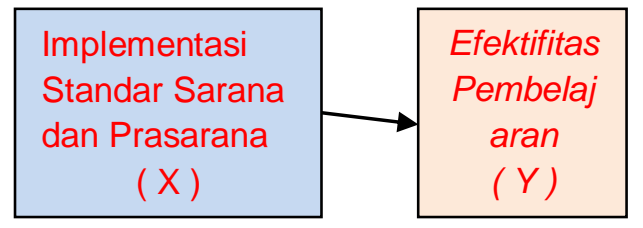


Jurnal Warna : Jurnal Pendidikan Dan Pembelajaran Anak Usia dini. September 2017. Vol 02. No. 02

\section{Analisis Data Untuk Menentukan pengaruh antar dua variabel terikat dengan variabel bebas}

Analisis regresi ganda ialah pengembangan dari analisis regresi sederhana, Kegunaan yaitu untuk memprediksi nilai variable terikat $(\mathrm{Y})$ apabila variable bebas minimal dua atau lebih. Analisis regresi ganda ini, bisa digunakan untuk mengetahui seberapa besar pengaruh variabel Implementasi Standar sarpras Terhadap Efektifitas Pembelajaran di TK AL Firdaus Kabupaten Jember. Analisis regresi ganda adalah suatu alat analisis peramalan data pengaruh dua variable bebas atau lebih terhadap variable terikat untuk membuktikan ada atau tidaknya hubungan fungsi atau hubungan kausal antara dua variable bebas atau lebih $\left(\mathrm{X}_{1}\right)$, $\left(\mathrm{X}_{2}\right),\left(\mathrm{X}_{3}\right), \ldots,\left(\mathrm{X}_{\mathrm{n}}\right)$, dengan satu variable terikat atau sebaliknya.

Asumsi dari persamaan regresi sederhana berlaku pada regresi ganda, namun perbedaan terletak pada rumusnya, sedangkan analisis regresi ganda dapat dihitung dengan cara computer dengan program Statistical Product Service Solutions (SPSS) versi versi 17; dan ada juga dengan menggunakan kalkulator atau manual.

Persamaan regresi ganda dirumuskan:

Dua Variabel Bebas : $\breve{y}=a+b_{1} X_{1}+b_{2} X_{2}$ Langkah-langkah menjawab Regresi Ganda :
Langkah 1. Membuat Ha dan Ho dalam bentuk kalimat

Langkah 2. Membuat Ha dan Ho dalam bentuk statistik :

Langkah 3. membuat tabel penolong untuk menghitung angka statistik :

Langkah 4. Hitung nilai-nilai persamaan $\mathrm{b}_{1}, \mathrm{~b}_{2}$ dan a dengan rumus : Rumus nilai persamaan untuk 2 variabel bebas cara pertama :

$$
\begin{aligned}
& \Sigma \mathrm{Y}=\mathrm{a} \cdot \mathrm{n}+\mathrm{b}_{1} \Sigma \mathrm{X}_{1}+\mathrm{b}_{2} \Sigma \mathrm{X}_{2} \\
& \Sigma \mathrm{X}_{1} \mathrm{Y}=\mathrm{a} \cdot \Sigma \mathrm{X}_{1}+\mathrm{b}_{2} \Sigma \mathrm{X}_{1}^{2}+\mathrm{b}_{2} . \Sigma \mathrm{X}_{1}+\mathrm{X}_{2}
\end{aligned}
$$

\section{PEMBAHASAN}

\section{Gambaran Umum Objek Penelitian}

Objek Penelitian adalah TK Al firdaus, sekolah objek penelitian ini ditinjau dari segi geografis banyak yang berkedudukan sangat strategis sehingga dapat dengan mudah dilalui oleh kendaraan roda dua, roda empat bahkan jalan kaki karena tidak jauh dari jalan raya, akan tetapi ada juga yang berlokasi di pedesaan/pegunungan yang cukup jauh sehingga untuk menempuh perjalanan menuju lokasi harus menempuh jarak 500 $\mathrm{m}$ hingga $1 \mathrm{~km}$ berjalan kaki, karena tidak adanya angkutan umum ataupun kerusakan infrastruktur/jalan yang cukup parah. Berkaitan dengan lokasi penelitian berikut ini dipaparkan deskripsi umum sekolah yang dijadikan lokasi tempat. 
Jurnal Warna : Jurnal Pendidikan Dan Pembelajaran Anak Usia dini. September 2017. Vol 02. No. 02

Ditinjau dari aspek demografis, data siswa sekolah ini cukup beragam, semua siswa tersebut berasal dari lapisan masyarakat yang beragam pula, baik dari faktor sosial, maupun faktor agama dan faktor ekonomi menengah ke bawah.

Dari profil sekolah sampel penelitian selanjutnya akan digambarkan kondisi sarana prasarana sekolah dan kualifikasi akademik tenaga pendidik sebagai berikut:

a. Responden penelitian terdiri atas 5 orang dengan jenis kelamin pria sebanyak 1 orang (75\%) sedangkan wanita sebanyak 4 orang (25\%).

b. Sebagian besar responden berusia antara $30 \mathrm{~s} / \mathrm{d} 40$ tahun sebanyak 4 orang ( $40,625 \%)$, sedangkan yang berusia diatas 40 tahun sebanyak 1 orang $(59,375 \%)$. Hal ini menunjukkan bahwa responden pada usia matang dan data yang diberikan dipertimbangkan dengan objektif dan sebaik-baiknya.

\section{Temuan Hasil Penelitian.}

Data hasil penelitian yang diperoleh melalui instrumen berbentuk kuesioner, kemudian diberi skor di setiap alternatif jawaban yang diberikan oleh responden sesuai dengan bobot yang telah ditetapkan. Setiap pernyataan dalam ketiga variabel memiliki 5 kriteria jawaban dengan pemberian skor dimulai dari 1, 2, 3, 4, dan 5 dengan ketentuan untuk pernyataan yang dihitung dengan hasil perhitungan deskriptif. Perhitungan angka persentase dari setiap variabel bertujuan untuk mengetahui kecenderungan umum jawaban responden terhadap variabel yaitu Implementasi Standar Sarana dan Prasarana (X), Efektifitas Pembelajaran d (Y).

Data hasil penelitian yang terkumpul dalam penelitian ini meliputi tiga variabel sebagaimana fokus permasalahan yang tergambar dalam pertanyaan penelitian. dua variabel tersebut yaitu:

a. Variabel Implementasi Standar Sarana dan Prasarana (X)

b. Variabel Efektifitas Pembelajaran TK Al firdaus $(\mathrm{Y})$

Data hasil penelitian tersebut diperoleh melalui instrumen yang berbentuk kuesioner. Selanjutnya dilakukan penskoran pada setiap alternatif jawaban yang diberikan oleh responden sesuai dengan bobot yang telah ditetapkan sebelumnya, yaitu bahwa setiap pernyataan dalam ketiga variabel memiliki 5 kriteria jawaban mulai dari 1 , 2, 3, 4, dan 5 dengan ketentuan untuk pernyataan yang dihitung dengan hasil perhitungan deskriptif.

Perhitungan angka persentase yang dilakukan pada setiap variabel dimaksudkan untuk mengetahui kecenderungan umum jawaban 
Jurnal Warna : Jurnal Pendidikan Dan Pembelajaran Anak Usia dini. September 2017. Vol 02. No. 02

responden terhadap variabel yang diungkap tersebut yang meliputi Implementasi Standar Sarana dan Prasarana $(\mathrm{X})$, dan Efektifitas Pembelajaran TK Al firdaus (Y) Angka prosentase variabel ini dihitung dengan rumus berikut:

$$
A P=\frac{\overline{X_{i}}}{\text { Sit }} \times 100 \%
$$

Dimana:

$A P=$ Angka Persentase yang dicari

$\overline{X_{i}}=$ Skor rata-rata (mean) setiap variabel

Sit $=$ Skor ideal setiap variabel

Hasil yang diperoleh, kemudian dikonsultasikan dengan kriteria intepretasi skor sebagaimana dikemukakan oleh Riduwan (2003:41) sebagai berikut:

Tabel Kriteria Interpretasi Skor
\begin{tabular}{|c|c|}
\hline SKOR & INTERPRETASI \\
PROSENTASE & \\
\hline $0 \%-19,99 \%$ & Sangat lemah \\
$20 \%-39,99 \%$ & Lemah \\
$40 \%-59,99 \%$ & Cukup \\
$60 \%-79,99 \%$ & Kuat \\
$80 \%-100 \%$ & Sangat Kuat \\
\hline
\end{tabular}

\section{Variabel Implementasi Standar \\ Sarana dan Prasarana}

Untuk menunjang proses pembelajaran, setiap sekolah menyediakan fasilitas berupa sarana dan prasarana yang lengkap dan memadai.Hasil observasi lapangan peneliti menemukan bahwa hanya 90,6 \% sekolah yang memiliki fasilitas lengkap dan baik sesuai dengan standar sarana prasarana berdasarkan permendiknas no.24 tahun 2007.

Kondisi ruang kelas di setiap sekolah $13,33 \%$ - 26,67\% dalam kondisi rusak ringan, sedangkan sisanya sangat layak pakai. Media pembelajaran berupa alat peraga, pembelajaran dsb juga lengkap, yang sangat memprihatinkan adalah komputer sekolah yang mencapai kerusakan 40-60\% terlebih lagi jumlah yang tidak memadai juga spesifikasi yang tertinggal jauh kebelakang .

\section{Pengujian Hipótesis}

Uji hipotesis dimaksudkan untuk mendapat kesimpulan apakah hipotesis penelitian yang dirumuskan didukung atau tidak didukung oleh data empiris.

Uji hipotesis dilakukan dengan analisis korelasi dan regresi tunggal maupun ganda. Dalam penelitian ini diajukan hipotesis penelitian, yaitu :

Terdapat hubungan antara Implementasi Standar Sarana dan Prasarana dengan Efektifitas Pembelajaran TK Al firdaus

Sebagaimana uji normalitas yang dikemukakan pada metode penelitian pada uji distribusi data diperoleh bahwa variabel Implementasi Standar Sarana dan Prasarana $(\mathrm{X})$, dan Efektifitas Pembelajaran TK Al firdaus (Y) berdistribusi normal sehingga dilanjutkan dengan uji statistik parametrik. Uji statistik yang dipilih yaitu untuk menguji hubungan antara variabel yang 
Jurnal Warna : Jurnal Pendidikan Dan Pembelajaran Anak Usia dini. September 2017. Vol 02. No. 02

dioperasionalkan dalam penelitian dengan uji korelasi Pearson Product Moment yang sudah tersedia melalui program SPSS for windows versi 17. Selengkapnya lampiran hasil pengolahan data menunjukkan persamaan regresi, sebagai berikut:

5. Tabel Konstanta Model Persamaan Regresi Variabel Implementasi Standar Sarana dan Prasarana dengan Efektifitas Pembelajaran TK Al firdaus

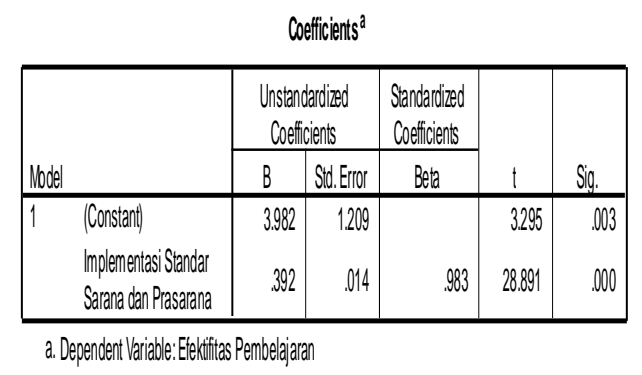

Dari hasil perhitungan analisis regresi linear sederhana mengenai hubungan antara Implementasi Standar Sarana dan Prasarana (X) dengan Efektifitas Pembelajaran TK Al fidaus (Y), diperoleh nilai konstanta $\mathrm{a}=$ 3.982 dan koefisien $b=0,392$, sehingga persamaan regresinya adalah $\hat{Y}=$ $3.982+0,392 \mathrm{X}$.

Hasil analisa regresi dengan persamaan $Y=a+b X=3.982+0,392$ $\mathrm{X}_{1}$. dapat dijelaskan konstanta sebesar 3.982 menyatakan bahwa jika tidak ada kenaikan nilai variabel Implementasi Standar Sarana dan Prasarana, maka nilai Efektifitas Pembelajaran TK AL Firdaus
3.982. Koefisien regresi sebesar 0,392 menyatakan bahwa setiap penambahan satu skor atau nilai Implementasi Standar Sarana dan Prasarana akan memberikan peningkatan pada skor Efektifitas Pembelajaran TK AL firdaus sebesar 0,392 atau setiap peningkatan Implementasi Standar Sarana dan Prasarana akan meningkatkan Efektifitas Pembelajaran TK AL firdaus sebesar 0,392

$$
\text { Persamaan } \hat{Y}=3.982+0,392 \mathrm{X}_{1} .
$$
kemudian diuji keberartian (signifikansi) arah koefisien dan kelinieran persamaannya dengan menggunakan analisis varians (Anova) yang diolah melalui SPSS for windows versi 17 sebagaimana ditunjukkan Tabel

Tabel Uji Linearitas Regresi dan Uji Signifikansi Variabel Implementasi Standar Sarana dan Prasarana (X) dengan Efektifitas Pembelajaran TK al firdaus,

\begin{tabular}{|c|c|c|c|c|c|c|}
\hline \multicolumn{7}{|c|}{ ANOVA $^{b}$} \\
\hline Model & & $\begin{array}{l}\text { Sum of } \\
\text { Squares }\end{array}$ & $d f$ & Mean Square & $\mathrm{F}$ & Sig. \\
\hline 1 & Regression & 403.951 & 1 & 403.951 & 834.710 & $.000^{2}$ \\
\hline & Residual & 14.518 & 30 & .484 & & \\
\hline 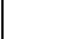 & Total & 418.469 & 31 & & & \\
\hline
\end{tabular}

a. Predictors: (Constant), Implementasi Standar Sarana dan Prasarana

b. Dependent Variable: Etektifitas Pembelajaran

Berdasarkan dari uji Anova atau $F_{\text {tes }}$ di dapat $F_{\text {hitung }}$ adalah 834,710 dengan tingkat signifikan $0,000 \quad$ karena probabilitas $(0,000)$ lebih kecil dari 0,05, dan $\mathrm{F}_{\text {hitung }}=834,710>\mathrm{F}_{\text {ttabel }}=3,92$ sehingga model regresi dapat dipakai untuk memprediksi Efektifitas Pembelajaran TK Alfirdaus atau 
Jurnal Warna : Jurnal Pendidikan Dan Pembelajaran Anak Usia dini. September 2017. Vol 02. No. 02

persamaan regresi $\hat{Y}=3.982+0,392$

$\mathrm{X}_{1 . .}$ signifikan dan linier.

Uji Signifikansi Korelasi Variabel

Implementasi Standar Sarana dan

Prasarana (X) dengan Efektifitas

Pembelajaran TK AL Firdaus (Y),

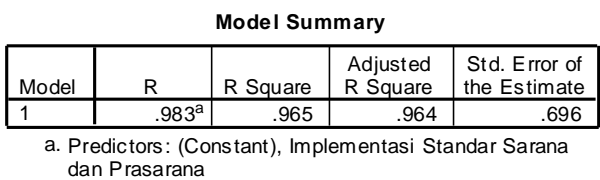

Berdasarkan uji signifikansi korelasi sebagaimana Tabel diatas disimpulkan bahwa koefisien korelasi antara Implementasi Standar Sarana dan Prasarana (X) dengan Efektifitas Pembelajaran TK AL firdaus (Y) sebesar 0,983 adalah signifikan, artinya bahwa kedua variabel yaitu variabel Implementasi Standar Sarana dan Prasarana dan Efektifitas Pembelajaran TK AL Firdaus mempunyai korelasi yang kuat atau tinggi. Sedangkan angka probabilitas didapat pada angka 0,00 dan angka tersebut berada di bawah 0,05, maka $\mathrm{H}_{\mathrm{o}}$ ditolak atau hipotesis diterima, artinya ada korelasi yang signifikan antara variabel Implementasi Standar Sarana dan Prasarana terhadap Efektifitas Pembelajaran TK AL Firdaus, atau terdapat hubungan positif antara Implementasi Standar Sarana dan Prasarana terhadap Efektifitas Pembelajaran TK AL Firdaus dan Koefisien determinasi $(\mathrm{KD})=0,965$ atau $96,5 \%$ dengan demikian 96,5 \% variabel Efektifitas Pembelajaran TK AL Firdaus (Y) dapat dijelaskan oleh Implementasi Standar Sarana dan Prasarana (X) sedangkan sisanya sebesar 3,5\% dihubungani oleh variabel lainnya, hal ini menunjukkan bahwa Implementasi Standar Sarana dan Prasarana turut memberikan hubungan positif dan signifikan terhadap Efektifitas Pembelajaran TK AL Firdaus sebesar $96,5 \%$, sedangkan $3,5 \%$ dihubungani oleh faktor lain seperti faktor motivasi belajar, kemampuan dasar, kondisi jasmani dan lingkungan

Berdasarkan uraian tersebut dapat ditunjukkan bahwa terdapat hubungan yang signifikan antara Implementasi Standar Sarana dan Prasarana dengan Efektifitas Pembelajaran TK AL Firdaus. Dengan demikian, hipotesis yang menyatakan "Terdapat hubungan antara Implementasi Standar Sarana dan Prasarana dengan Efektifitas Pembelajaran TK AL Firdaus" dapat diterima. Ini berarti bahwa semakin tinggi Implementasi Standar Sarana dan Prasarana maka semakin meningkat pula Efektifitas Pembelajaran TK AL Firdaus

Sesuai dengan deskripsi tersebut diatas berarti bahwa Implementasi Standar Sarana dan Prasarana memberi hubungan positif dan signifikan terhadap Efektifitas Pembelajaran TK AL Firdaus sebesar 96,5\%, yang berarti bahwa 
Jurnal Warna : Jurnal Pendidikan Dan Pembelajaran Anak Usia dini. September 2017. Vol 02. No. 02

peningkatan Efektifitas Pembelajaran TK

AL Firdaus terjadi disebabkan oleh

Implementasi Standar Sarana dan

Prasarana sebesar 96,5\% dan sisanya

$3,5 \%$ ditentukan oleh faktor lain yang tidak termasuk dalam penelitian ini seperti faktor motivasi belajar,

kemampuan dasar, kondisi jasmani dan lingkungan. Kontribusi Implementasi Standar Sarana dan Prasarana ini tergolong pada katagori cukup tinggi.

Dari deskripsi data, perhitungan persentasi, korelasi dan regresi dapat diketahui bahwa temuan penelitian tersebut menunjukkan bahwa secara keseluruhan Implementasi Standar Sarana dan Prasarana oleh pemerintah mempunyai efektifitas yang cukup tinggi terhadap peningkatan Efektifitas

Pembelajaran TK AL Firdaus

Implementasi Standar Sarana dan Prasarana berkorelasi positif terhadap Efektifitas Pembelajaran TK AL Firdaus secara signifikan.

Keeratan hubungan antara

Implementasi Standar Sarana dan Prasarana dan Efektifitas Pembelajaran TK AL Firdaus diperoleh koefisien korelasi sebesar 0,983 dengan koefisien determinasi sebesar 0,965 atau 96,5\%. Gambaran ini menunjukkan bahwa Efektifitas Pembelajaran TK AL Firdaus dihubungani oleh faktor Implementasi Standar Sarana dan Prasarana sebesar $96,5 \%$, sisanya sebesar $3,5 \%$ dihubungani oleh faktor lain yang tidak dikaji dalam penelitian ini, seperti faktor motivasi belajar, kemampuan dasar, kondisi jasmani dan lingkungan.

Hasil pengujian hipotesis pertama telah memperlihatkan bukti empiris adanya pengaruh yang posistif dan signifikan antara sarana dan prasarana peningkatan kompetensi guru dengan Efektifitas Pembelajaran . Hasil analisis data juga menunjukan bahwa besarnya angka Koefisien Determinasi dalam perhitungan diatas ialah 0,745 atau sama dengan 74,5 artinya besarnya pengaruh sarana dan prasarana peningkatan kompetensi guru terhadap Efektifitas Pembelajaran $74,5 \%$. Sedangkan sisanya $25,5 \%$ harus dijelaskan oleh faktor-faktor penyebab lainnya. Hal ini mengandung pengertian semakin tinggi sarana dan prasarana untuk kompetensi guru maka makin tinggi pula Efektifitas Pembelajaran .

\section{PENUTUP}

\section{KESIMPULAN}

Berdasarkan hasil penelitian dapat dikemukakan bahwa salah satu upaya yang dapat dilakukan untuk meningkatkan Efektifitas Pembelajaran adalah dengan cara meningkatkan sarana dan prasarana untuk peningkatan kompetensi guru.Implikasi peningkatan sarana dan prasarana ini diharapkan mampu meningkatkan kompetensi guru 
Jurnal Warna : Jurnal Pendidikan Dan Pembelajaran Anak Usia dini. September 2017. Vol 02. No. 02

yang menunjang kearah perbaikan mutu proses dan hasil pembelajaran.

Sarana Prasarana sekolah yang lengkap dan memadai merupakan salah satu faktor yang sangat menunjang pada kegiatan pembelajaran untuk memperoleh hasil atau tujuan yang akan dicapai. Implikasi dari peningkatan sarana dan prasarana diharapkan mampu meningkatkan Efektifitas Pembelajaran dengan penggunaan yang optimal.

Untuk mengurangi adanya perbedaan biaya yang terlalu kontras dan juga disparitas mutu antar sekolah, maka pemerintah sebaiknya lebih mengalokasikan dana ataupun sarana prasarana terhadap sekolah-sekolah dengan jumlah murid yang terbatas.

\section{DAFTAR PUSTAKA}

Arikunto, Suharsimi. 1993. Prosedur Penelitian: Suatu Pendekatan Praktek. Rineka Cipta: Jakarta

Bafadal, I. (2004). Manajemen Perlengkapan Sekolah Teori dan Aplikasinya: Seri Manajemen Peningkatan Mutu Pendidikan Berbasis Sekolah Jakarta : Bumi Aksara.

Depdiknas (2008). Informasi Program Derektorat Pembinaan Sekolah Menengah Pertama

Depdiknas (2006). Pedoman Umum Pemilihan Alat Peraga/Praktik Pendidikan Sekolah Menengah Pertama (SMP) Jakarta

Dinas Pendidikan Kota Bandung, Rencana Strategis Tahun 2004-2008
Keputusan Mendikbud. Nomor 020/U/1998 tentang Petunjuk Teknis Pelaksanaan Jabatan Fungsional Pengawas Sekolah dan Angka Kreditnya.

Mulyasa, E. (2004). Manajemen Berbasis Sekolah Konsep, Strategi, dan Implementasi Bandung : Remaja Rosda Karya

Peraturan Daerah Kota Bandung. Nomor 02 Tahun 2001 tentang Kewenangan Daerah Kota Bandung sebagai Daerah Otonom.

Peraturan Pemerintah Republik Indonesia Nomor 19 Tahun 2005 tentang Standar Nasional Pendidikan, Jakarta : Sinar Grafika

Peraturan Pemerintah Republik Indonesia Nomor 38 Tahun 2007 tentang Pembagian Urusan Pemerintah antara pemerontah, pemerintah Daerah Propinsi dan Pemerintah Daerah Kabupaten Kota

Permendiknas Republik Indonesia. Nomor 24 Tahun 2007 tentang standar sarana prasarana

Permendiknas Republik Indonesia. Nomor 12 Tahun 2007 tentang standar Pengawas Sekolah

Permendiknas Republik Indonesia. Nomor 13 Tahun 2007 tentang standar Kepala Sekolah

Permendiknas Republik Indonesia. Nomor 19 Tahun 2007 tentang standar Pengelolaan

Sukmadinata, N. (2007). Metode Penelitian Pendidikan Bandung: Remaja Rosdakarya

Surakhmad, W. (1980) Pengantar Penelitian Ilmiah. Bandung: Tarsito

Surya D. (2008) Jurnal Tenaga Kependidikan, Volume 3 Nomor 1

Surya, M. (2003). Psikologi Pembelajaran dan Pengajaran Bandung; Yayan Bhakti Winaya 
Jurnal Warna : Jurnal Pendidikan Dan Pembelajaran Anak Usia dini. September 2017. Vol 02. No. 02

Undang undang Republik Indonesia. Nomor 24 Tahun 2003 tentang Sistem Pendidikan Nasional, Jakarta :Dharma Bhakti
Undang undang Republik Indonesia. Nomor 14 Tahun 2005 tentang Sistem Guru dan Dosen, Jakarta :Dharma Bhakti 